\title{
Idarubicin, an Anthracycline, Induces Oxidative DNA Damage in the Presence of Copper (II)
}

\author{
HIDEKI MIZUTANI $^{1}$, CHIAKI SHIGA ${ }^{1}$, MASANORI IMAI $^{1}$, KENJI IKEMURA $^{1,2}$, \\ YUKI KITAMURA ${ }^{1}$, KINYA OHTA $^{1}$, DAISUKE MIYAZAWA ${ }^{1}$, MAYUKO SAKANASHI ${ }^{1}$, \\ TOMOKO TAHIRA ${ }^{1}$, TOHRU MAEDA ${ }^{1}$, YUSUKE HIRAKU ${ }^{3}$ and SHOSUKE KAWANISHI ${ }^{4}$ \\ ${ }^{1}$ College of Pharmacy, Kinjo Gakuin University, Nagoya, Japan; \\ ${ }^{2}$ Department of Pharmacy, Osaka University Hospital, Suita, Japan; \\ ${ }^{3}$ Department of Environmental Health, University of Fukui School of Medical Sciences, Eiheiji, Japan; \\ ${ }^{4}$ Faculty of Pharmaceutical Sciences, Suzuka University of Medical Science, Suzuka, Japan
}

\begin{abstract}
Background/Aim: The aim of the present study was to investigate whether idarubicin (IDR) induces oxidative DNA damage in the presence of copper (II). Materials and Methods: DNA damage was evaluated by pBR322 plasmid DNA cleavage. The formation of oxidative stress markers $\mathrm{IO}_{2}{ }^{--}$and 8-hydroxy-2'-deoxyguanosine (8$\mathrm{OHdG})]$ was analysed. Results: IDR induced DNA damage and $\mathrm{O}_{2}{ }^{\circ-}$ and 8-OHdG generation in the presence of copper (II). Conclusion: IDR induced oxidative DNA damage in the presence of copper (II). Since it has been reported that the concentration of copper in the serum of cancer patients is higher than that in healthy groups, IDR-induced oxidative DNA damage in the presence of copper (II) may play an important role in anticancer therapeutic strategies.
\end{abstract}

Idarubicin (IDR, 4-demethoxydaunorubicin) is an anthracycline anticancer agent that was developed by Arcamone et al. in 1976 (1). They synthesized IDR by the removal of the methoxyl group at the C-4 position of daunorubicin (1). IDR has a higher lipophilicity, cell-permeability and cytotoxicity than daunorubicin and doxorubicin (2), and is more effective against doxorubicin-, daunorubicin- and aclarubicin-resistant cancer cell lines (3). Furthermore, the relative cardiotoxicity of IDR is lower than that of doxorubicin and epirubicin (4). IDR is presently used as an important standard drug for treating acute myeloid leukemia combined with cytarabine, similar to daunorubicin (5).

This article is freely accessible online.

Correspondence to: Hideki Mizutani, Ph.D., College of Pharmacy, Kinjo Gakuin University, Moriyama-ku, Nagoya 463-8521, Japan. Tel: +81 527987458, Fax: +81 527980754, e-mail: mizu@kinjo-u.ac.jp

Key Words: Idarubicin, DNA damage, ROS, copper.
DNA damage is one of the important anticancer mechanisms of anthracyclines including IDR $(6,7)$. Anthracyclines induce oxidative DNA damage by NADPH-cytochrome $\mathrm{P} 450$ reductase $(8,9)$. IDR also induces reactive oxygen species (ROS) generation and oxidative DNA damage by NADPH-cytochrome P450 reductase (10). It has been reported that IDR activated by NADPH-cytochrome P450 reductase induces DNA damage in breast cancer cell lines (11). Meanwhile, we have reported that anthracyclines (doxorubicin, amrubicin, aclarubicin and pirarubicin) induce oxidative DNA damage in the presence of copper (II) (12-15). However, it is unclear how IDR induces oxidative DNA damage in the presence of copper (II). In the present study, we investigated IDR-induced DNA damage in the presence of copper (II), and showed that IDR increased the formation of oxidative stress markers $\left[\mathrm{O}_{2}^{--}\right.$and 8-hydroxy-2'deoxyguanosine $(8-\mathrm{OHdG})]$ in the presence of copper (II).

\section{Materials and Methods}

Materials. Idarubicin hydrochloride, superoxide dismutase (SOD; $3,000 \mathrm{U} / \mathrm{mg}$ from bovine erythrocytes), catalase $(45,000 \mathrm{U} / \mathrm{mg}$ from bovine liver) and cytochrome $c$ (from equine heart) were obtained from Sigma-Aldrich Co. (St. Louis, MO, USA). Doxorubicin hydrochloride was obtained from FUJIFILM Wako Pure Chemical Co. (Osaka, Japan). Plasmid DNA (pBR322) was obtained from Takara Bio Inc. (Kusatsu, Japan) and DNA gel loading dye (6x) was from Toyobo Co., Ltd. (Osaka, Japan). Calf thymus DNA was obtained from Worthington Biochemical Co. (Lakewood, NJ, USA) and copper chloride $\left(\mathrm{CuCl}_{2} \bullet 2 \mathrm{H}_{2} \mathrm{O}\right)$ was from Nacalai Tesque Inc. (Kyoto, Japan). Diethylenetriamine- $N, N, N$ ', $N$ ", $N$ "'-penta-acetic acid (DTPA) and bathocuproinedisulfonic acid were obtained from Dojindo Laboratories Co. (Kumamoto, Japan) and methional [3(methylthio)propionaldehyde] was from Tokyo Chemical Industry Co., Ltd. (Tokyo, Japan). All other chemicals used were of the highest grade commercially available.

Detection of DNA damage induced by anthracyclines in the presence of copper (II). The reaction mixture was placed in $1.5 \mathrm{ml}$ 
microcentrifuge tubes (3810X, Eppendorf AG, Hamburg, Germany) and contained an anthracycline, $20 \mu \mathrm{M} \mathrm{CuCl}_{2}$ and pBR322 plasmid DNA $(0.2 \mu \mathrm{g} /$ tube $)$ in $50 \mu \mathrm{l}$ of $10 \mathrm{mM}$ sodium phosphate buffer $(\mathrm{pH}$ 7.8) that contained $5 \mu \mathrm{M}$ DTPA, a chelator for removing trace amounts of contaminated metals. After incubation at $37^{\circ} \mathrm{C}$ for 60 min, the reacted DNA was analyzed by gel electrophoresis as described in previous reports (14-16).

Detection of efficacy of ROS scavengers and bathocuproine in protecting DNA from IDR-induced damage in the presence of copper (II). The reaction mixture was placed in $1.5 \mathrm{ml}$ microcentrifuge tubes contained $20 \mu \mathrm{M}$ IDR, $20 \mu \mathrm{M} \mathrm{CuCl} 2$, pBR322 plasmid DNA $(0.2$ $\mu \mathrm{g} /$ tube) in $50 \mu \mathrm{l}$ of $10 \mathrm{mM}$ sodium phosphate buffer ( $\mathrm{pH} 7.8$ ) that contained $5 \mu \mathrm{M}$ DTPA with ROS scavengers or bathocuproine. The concentration of ROS scavengers was $1.7 \mathrm{M}(10 \%)$ ethanol, $0.1 \mathrm{M}$ mannitol, $0.1 \mathrm{M}$ sodium formate, $0.7 \mathrm{M}$ (10\%) DMSO, 50 or 100 units of SOD, 50 or 100 units of catalase, and $0.1 \mathrm{M}$ methional. The concentration of bathocuproine was $50 \mu \mathrm{M}$. After incubation at $37^{\circ} \mathrm{C}$ for $60 \mathrm{~min}$, the reacted DNA was detected by gel electrophoresis as described in previous reports (14-16).

Analysis of $\mathrm{O}_{2}{ }^{-}$derived from IDR in the presence of copper (II). To analyse $\mathrm{O}_{2}{ }^{\circ-}$ production induced by IDR, $100 \mu \mathrm{M}$ cytochrome $c$ was added to a reaction solution containing $20 \mu \mathrm{M}$ IDR and $20 \mu \mathrm{M}$ $\mathrm{Cu}(\mathrm{II})$ in $1 \mathrm{ml}$ of $10 \mathrm{mM}$ sodium phosphate buffer ( $\mathrm{pH}$ 7.8) with 2.5 $\mu \mathrm{M}$ DTPA. Ferrocytochrome $c$ produced by the reduction of ferricytochrome $c$ has an absorption maximum at $550 \mathrm{~nm}$; absorption was measured at $37^{\circ} \mathrm{C}$ with a UV-visible spectrophotometer (UV-2600; Shimadzu, Kyoto, Japan). The increased amounts of reduced cytochrome $c$ were calculated by subtracting the absorbance in the presence of $100 \mathrm{U} / \mathrm{ml} \mathrm{SOD} \mathrm{from}$ that without SOD at $550 \mathrm{~nm}\left(\varepsilon=21.1 \times 10^{3} \mathrm{M}^{-1} \mathrm{~cm}^{-1}\right)(17)$.

Analysis of 8-OHdG generation in calf thymus DNA by IDR in the presence of copper (II). Calf thymus DNA fragments $(20 \mu \mathrm{g} / \mathrm{tube})$ were incubated with IDR and $20 \mu \mathrm{M} \mathrm{CuCl}_{2}$ in $200 \mu \mathrm{l}$ of $4 \mathrm{mM}$ sodium phosphate buffer $(\mathrm{pH} 7.8)$ that contained $5 \mu \mathrm{M}$ DTPA at $37^{\circ} \mathrm{C}$ for $60 \mathrm{~min}$. After ethanol precipitation, the reacted DNA was digested to nucleosides with nuclease $\mathrm{P} 1$ and calf intestine alkaline phosphatase (12). The generated 8-OHdG were analyzed by Highly Sensitive 8-OHdG Check ELISA (Nikken SEIL Co., Fukuroi, Japan) according to the manufacturer's instructions (18).

Statistical analysis. All statistical analyses were carried out using Kaleida Graph version 4.1.3 (Synergy Software, Reading, PA, USA). ANOVA followed by Tukey's HSD test was performed to compare differences between the test groups and the control groups. Student's $t$-test was performed to compare differences between the test groups. Values of $p<0.05$ were regarded as statistically significant.

\section{Results}

IDR-induced DNA damage in the presence of copper (II). Figure 1 indicates the electrophoretic profiles of the damage of pBR322 plasmid DNA induced by IDR and doxorubicin. Twenty $\mu \mathrm{M}$ of IDR induced DNA damage in a timedependent manner in the presence of copper (II) (Figure 1A). IDR induced apparent DNA damage at 20,30 and $60 \mathrm{~min}$ of incubation. The extent of DNA damage was IDRconcentration-dependent in the presence of copper (II) at 60 min of incubation (Figure 1B). IDR induced no or little DNA damage at 1,2 and $5 \mu \mathrm{M}$, and apparent DNA damage above $10 \mu \mathrm{M}$ in the presence of copper (II), resulting in the detection of a smear DNA band on the agarose gel at $20 \mu \mathrm{M}$. Copper (II) or IDR alone did not induce DNA damage. IDR did not induce DNA damage in the presence of other metals [iron(III), iron(II), zinc(II), nickel(II), magnesium(II), cobalt(II) or mangan(II)] (data not shown). On the other hand, doxorubicin caused greater DNA damage compared to IDR (Figure 1C). Doxorubicin caused no DNA damage at 1 and $2 \mu \mathrm{M}$, and apparent DNA damage at $5 \mu \mathrm{M}$ in the presence of copper (II). Doxorubicin induced strong DNA damage at 10 and $20 \mu \mathrm{M}$ in the presence of copper (II), resulting in a smear DNA band detection on the agarose gel. Copper (II) or doxorubicin alone did not cause DNA damage.

Efficacy of ROS scavengers and bathocuproine in protecting DNA from IDR-induced damage in the presence of copper (II). Figure 2 indicates the efficacy of ROS scavengers or bathocuproine on the DNA damage induced by IDR in the presence of copper (II). Typical $\bullet \mathrm{OH}$ scavengers, ethanol, mannitol, sodium formate and DMSO, had little or no inhibitory effect on IDR-induced DNA damage (Figure 2A). SOD, catalase and methional had little inhibitory effect on IDR-induced DNA damage, and bathocuproine completely prevented DNA damage (Figure 2B).

Analysis of $\mathrm{O}_{2}{ }^{--}$derived from $\mathrm{IDR}$ in the presence of copper (II). Figure 3A indicates the levels of IDR-induced cytochrome $c$ reduction in the presence of copper (II). Incubation of cytochrome $c$ in the presence of IDR and copper (II) resulted in a time-dependent increase in cytochrome $c$ reduction. Upon addition of SOD, the levels of reduced cytochrome $c$ decreased significantly, suggesting the production of $\mathrm{O}_{2}{ }^{-}$. The results showed that $\mathrm{O}_{2}{ }^{-}$generation by $20 \mu \mathrm{M}$ IDR was approximately $1.5 \mu \mathrm{M}$ in the presence of $20 \mu \mathrm{M}$ copper (II). The inhibitory effect of SOD on cytochrome $c$ reduction was partial. These findings suggest the presence of mechanisms of $\mathrm{O}_{2}{ }^{--}$independent cytochrome $c$ reduction that were probably mediated by $\mathrm{Cu}(\mathrm{I})$.

Generation of 8-OHdG in calf thymus DNA by IDR in the presence of $\mathrm{Cu}(I I)$. 8-OHdG is an oxidative stress marker, and one of the DNA adducts generated by ROS. The increased levels of 8-OHdG were significantly dependent on the IDR concentration used in the presence of copper (II) (Figure 3B). The generation of 8-OHdG increased about 3.5fold with $50 \mu \mathrm{M}$ IDR in the presence of copper (II) compared with the control. 

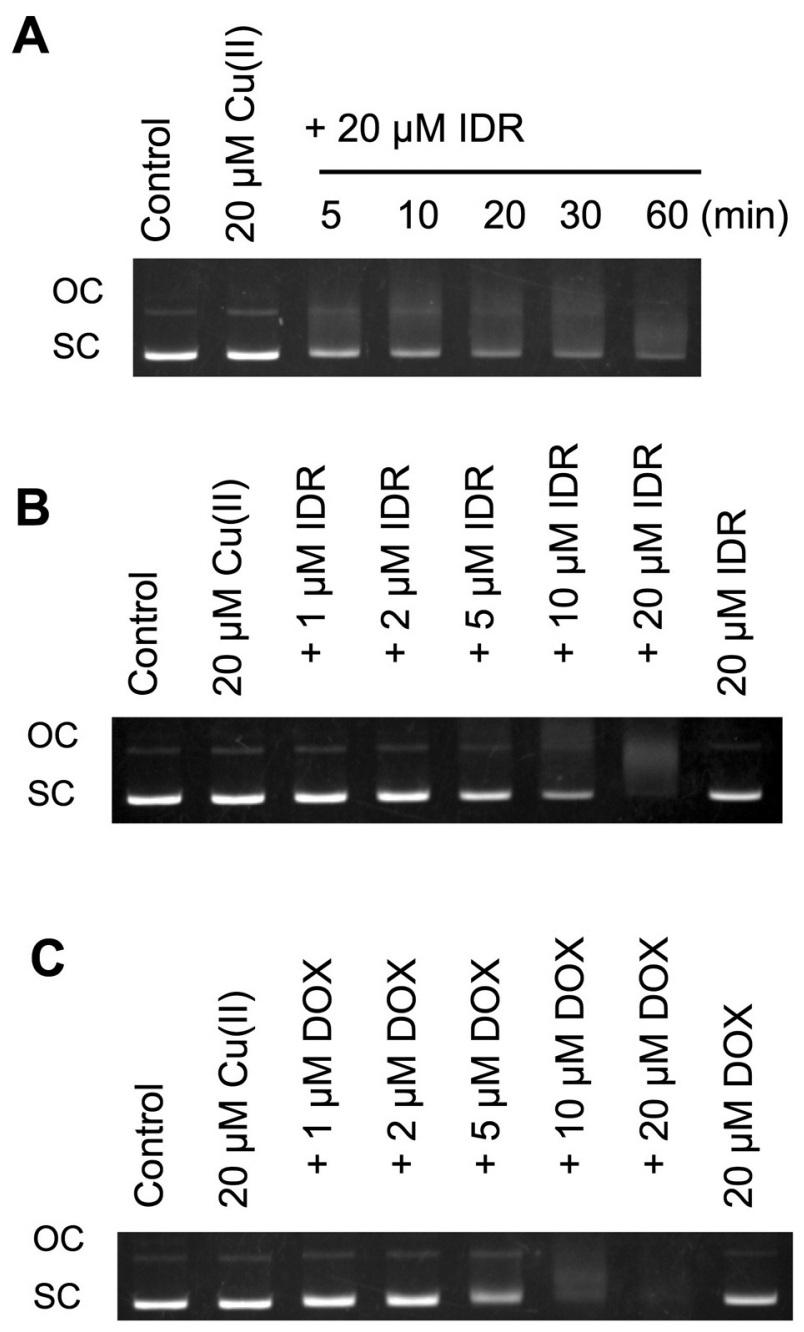

Figure 1. Analysis of DNA damage induced by idarubicin (IDR) or doxorubicin (DOX) in the presence of copper (II). A: pBR322 plasmid $D N A$ reacted with the indicated concentrations of IDR in the presence of $20 \mu \mathrm{M} \mathrm{CuCl}_{2}$ for $1 \mathrm{~h}$. B: pBR322 plasmid DNA reacted with $20 \mu \mathrm{M}$ IDR in the presence of $20 \mu \mathrm{M} \mathrm{CuCl} l_{2}$ for the indicated times. $C: p B R 322$ plasmid DNA reacted with the indicated concentrations of DOX in the presence of $20 \mu \mathrm{M} \mathrm{CuCl} l_{2}$ for $1 \mathrm{~h}$. The supercoiled (SC) and open circular (OC) forms of DNA are indicated.

\section{Discussion}

The present work demonstrated that oxidative DNA damage was induced by IDR in the presence of copper (II) in a cellfree system. IDR-induced oxidative DNA damage was less than the doxorubicin-induced oxidative DNA damage, and corresponded to less cardiotoxic effects in an isolated perfused rat heart model (19). Typical $\bullet \mathrm{OH}$ scavengers, SOD, catalase and methional had little or no inhibitory effect on IDRinduced DNA damage. Bathocuproine, as a copper (I)
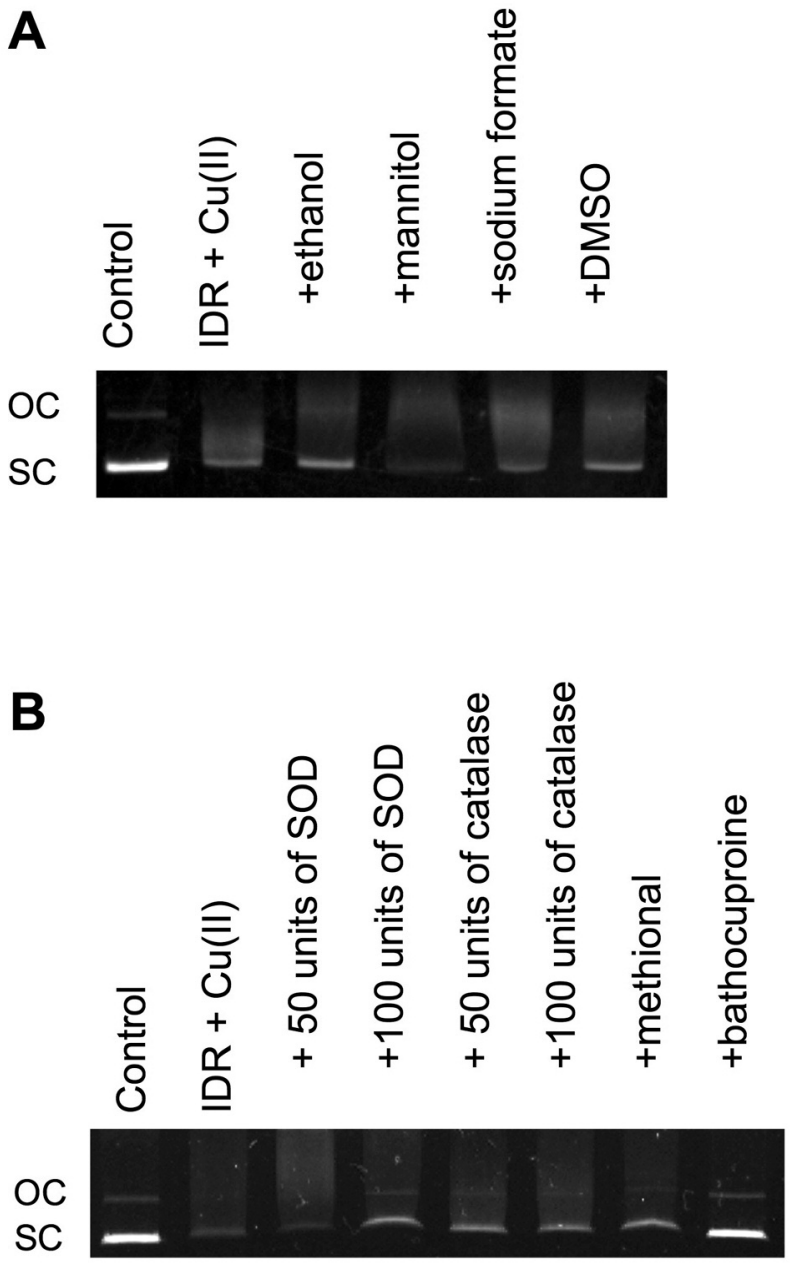

Figure 2. Inhibiting effect of ROS scavengers and bathocuproine on DNA damage induced by idarubicin (IDR) in the presence of copper (II). pBR322 plasmid DNA reacted with $20 \mu M$ IDR in the presence of $20 \mu \mathrm{M} \mathrm{CuCl} l_{2}$ for $1 \mathrm{~h}$ with and without $1.7 \mathrm{M}$ (10\%) ethanol, $0.1 \mathrm{M}$ mannitol, $0.1 \mathrm{M}$ sodium formate, $0.7 \mathrm{M}$ (10\%) dimethyl sulfoxide (DMSO), 50 or 100 units of SOD, 50 or 100 units of catalase, $0.1 \mathrm{M}$ methional, or $50 \mu \mathrm{M}$ bathocuproine. The supercoiled (SC) and open circular $(O C)$ forms of DNA are indicated.

chelator, completely inhibited DNA damage. Moreover, we observed that IDR induced $\mathrm{O}_{2}^{--}$production and $8-\mathrm{OHdG}$ generation in the presence of copper (II). IDR-induced oxidative DNA damage was confirmed by $\mathrm{O}_{2}{ }^{--}$production and $8-\mathrm{OHdG}$ formation in the presence of copper (II), whereas - OH scavengers, SOD, catalase and methional had little or no inhibitory effect on IDR-induced oxidative DNA damage.

Our previous reports have revealed that oxidative DNA damage was induced by anthracyclines such as doxorubicin, amrubicin, aclarubicin and pirarubicin via oxidation of 
A

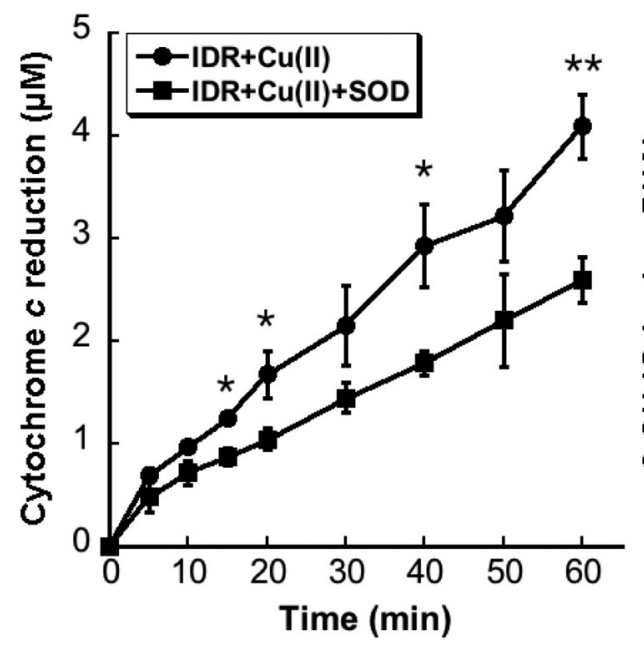

B

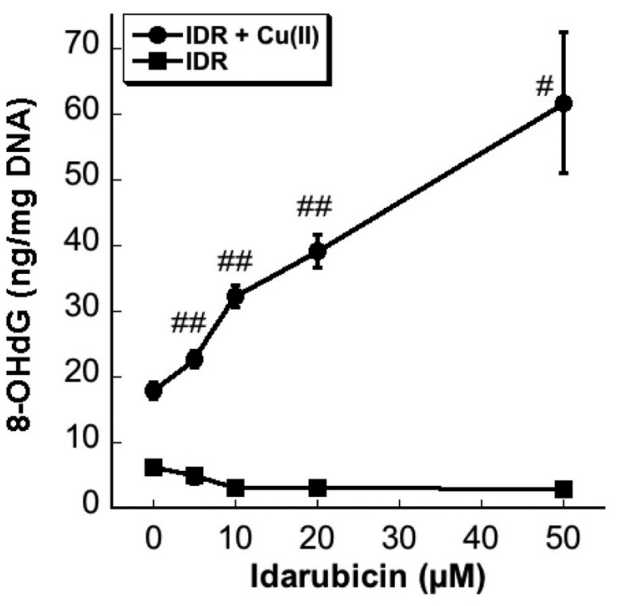

Figure 3. Cytochrome c reduction and 8-hydroxy-2'-deoxyguanosine (8-OHdG) generation by idarubicin (IDR) in the presence of copper (II). A: The reaction solution contained $100 \mu \mathrm{M}$ cytochrome c, $20 \mu \mathrm{MIDR}$ and $20 \mu \mathrm{M} \mathrm{CuCl}{ }_{2}$. Absorption at $550 \mathrm{~nm}$ was measured at $37^{\circ} \mathrm{C}$ with a UVvisible spectrophotometer. The increased levels of $\mathrm{O}_{2}{ }^{-}$- production were calculated by subtracting absorbance with $100 \mathrm{U} / \mathrm{ml}$ SOD from that without $S O D$ at $550 \mathrm{~nm}\left(\varepsilon=21.1 \times 10^{3} \mathrm{M}^{-1} \mathrm{~cm}^{-1}\right)$. B: Calf thymus DNA fragments were incubated with IDR and $20 \mu \mathrm{M} \mathrm{CuCl}{ }_{2}$ at $37^{\circ} \mathrm{C}$ for $60 \mathrm{~min}$. After ethanol precipitation, the reacted DNA was digested to nucleosides with nuclease P1 and calf intestine alkaline phosphatase. The generated 8OHdG was analyzed by Highly Sensitive 8-OHdG Check ELISA (Nikken SEIL Co., Fukuroi, Japan). The data are presented as means \pm SD ( $n=3$ ). Significantly different at ${ }^{*} p<0.05$ and ${ }^{* *} p<0.01$ by the Student's $t$-test; ${ }^{\#} p<0.05$ and ${ }^{\# \#} p<0.01$ vs. control by ANOVA followed by Tukey's HSD test.

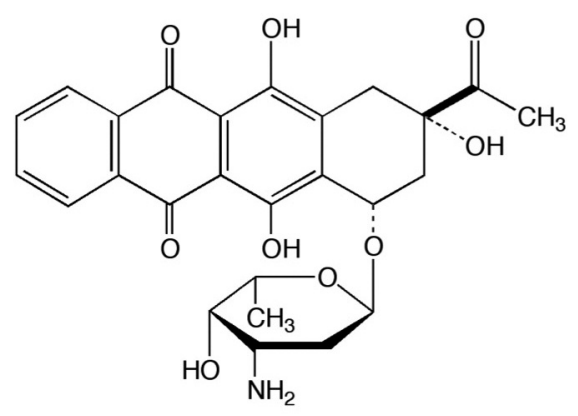

Idarubicin
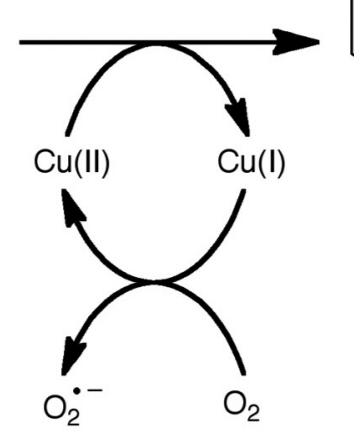

$\downarrow$

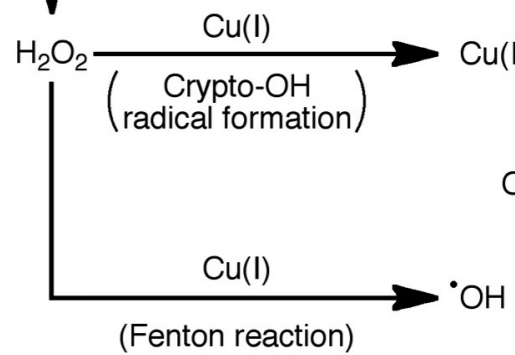<smiles></smiles>

Semiquinone radical (Oxidized form)

Figure 4. Possible mechanisms for oxidative DNA damage induced by idarubicin in the presence of copper (II). 
$p$-hydroquinone in the presence of copper (II) (12-15). IDR has an anthraquinone portion similarly to the other anthracyclines. Hence, it seems that the oxidative DNA damage induced by IDR in the presence of copper (II) proceeds via a mechanism identical to that of the other anthracyclines. We advocated the possible mechanism of the oxidative DNA damage induced by IDR. Copper (II)mediated one-electron oxidation is caused by IDR at the $\mathrm{OH}$ group on the anthraquinone aromatic ring, producing copper (I) and the semiquinone radical. Copper (I) causes $\mathrm{O}_{2}{ }^{--}$ generation from $\mathrm{O}_{2}$, and subsequently the production of $\mathrm{H}_{2} \mathrm{O}_{2} \cdot \mathrm{H}_{2} \mathrm{O}_{2}$ interacts with copper (I), resulting in the formation of $\mathrm{Cu}(\mathrm{I}) \mathrm{OOH}$ via the crypto-OH radical or that of -OH via the Fenton reaction (20). Finally, $\mathrm{Cu}(\mathrm{I}) \mathrm{OOH}$ and - $\mathrm{OH}$ may cause DNA damage (Figure 4). However, methional and $\bullet \mathrm{OH}$ scavengers had little or no inhibitory effect on IDRinduced DNA damage. Methional inhibits other radicals, for example, metal-oxygen complexes as well as $\bullet \mathrm{OH}$ (21). In our previous studies, methional inhibited DNA damage induced by doxorubicin, aclarubicin or pirarubicin in the presence of copper (II), and $\bullet \mathrm{OH}$ scavengers did not inhibit the DNA damage, suggesting that the DNA damage was induced by $\mathrm{Cu}(\mathrm{I}) \mathrm{OOH}$, not $\bullet \mathrm{OH}$. On the other hand, IDR has higher affinity with DNA than the other anthracyclines (22), therefore methional and $\bullet \mathrm{OH}$ scavengers may be ineffective for IDR-induced DNA damage. The complete inhibition of IDR-induced DNA damage by bathocuproine, a copper (I) chelator, indicates that copper (I) is a key molecule for IDRinduced DNA damage in the presence of copper (II).

It has been reported that anthracyclines induce ROS generation and oxidative DNA damage by NADPHcytochrome P450 reductase (6-9). IDR also induces ROS generation and oxidative DNA damage by NADPHcytochrome P450 reductase (10). However, we have shown that anthracyclines such as doxorubicin, amrubicin, aclarubicin and pirarubicin induced oxidative DNA damage in the presence of copper (II) (12-15). This oxidative DNA damage in the presence of copper (II) is more effective than DNA damage caused by NADPH-cytochrome P450 reductase (12). Furthermore, our and other groups have reported that other anticancer agents as well as anthracyclines induce oxidative DNA damage in the presence of copper (II) (23-29). The concentration of copper in the serum of cancer patients is higher than that in healthy groups, and is correlated with the malignancy grade of cancer patients (30). Therefore, oxidative DNA damage induced by IDR in the presence of copper (II) may play an important role in anticancer therapeutic strategies.

\section{Conflicts of Interest}

The Authors have no conflicts of interest to declare in relation to this study.

\section{Authors' Contributions}

H.M. and C.S. performed the most experimental work; all Authors participated in data analysis; H.M. and S.K. designed and coordinated the study; H.M. drafted the manuscript; K.I. and S.K. revised the manuscript. All Authors gave final approval for publication.

\section{Acknowledgements}

This work was partially supported by JSPS (the Japan Society for the Promotion of Science) KAKENHI Grant Number 16K08420.

\section{References}

1 Arcamone F, Bernardi L, Giardino P, Patelli B, Marco A, Casazza AM, Pratesi G and Reggiani P: Synthesis and antitumor activity of 4-demethoxydaunorubicin, 4-demethoxy-7,9diepidaunorubicin, and their beta anomers. Cancer Treat Rep 60(7): 829-834, 1976. PMID: 1009518.

2 Supino R, Necco A, Dasdia T, Casazza A M and Marco A Di: Relationship between effects on nucleic acid synthesis in cell cultures and cytotoxicity of 4-demethoxy derivatives of daunorubicin and adriamycin. Cancer Res 37(12): 4523-4528, 1977. PMID: 922737.

3 Tsuruo T, Oh-Hara T, Sudo Y and Naito M: Antitumor activity of idarubicin, a derivative of daunorubicin, against drug sensitive and resistant P388 leukemia. Anticancer Res 13(2): 357-361, 1993. PMID: 8517647.

4 McGowan JV, Chung R, Maulik A, Piotrowska I, Walker JM and Yellon DM: Anthracycline chemotherapy and cardiotoxicity. Cardiovasc Drugs Ther 31(1): 63-75, 2017. PMID: 28185035. DOI: 10.1007/s10557-016-6711-0

5 Adige S, Lapidus RG, Carter-Cooper BA, Duffy A, Patzke C, Law JY, Baer MR, Ambulos NP, Zou Y, Bentzen SM and Emadi A: Equipotent doses of daunorubicin and idarubicin for AML: a meta-analysis of clinical trials versus in vitro estimation. Cancer Chemother Pharmacol 83(6): 1105-1112, 2019. PMID: 30968179. DOI: $10.1007 / \mathrm{s} 00280-019-03825-2$

6 Gewirtz DA: A critical evaluation of the mechanisms of action proposed for the antitumor effects of the anthracycline antibiotics adriamycin and daunorubicin. Biochem Pharmacol 57(7): 727-741, 1999. PMID: 10075079. DOI: 10.1016/s00062952(98)00307-4

7 Minotti G, Menna P, Salvatorelli E, Cairo G and Gianni L: Anthracyclines: molecular advances and pharmacologic developments in antitumor activity and cardiotoxicity. Pharmacol Rev 56(2): 185-229, 2004. PMID: 15169927. DOI: 10.1124/pr.56.2.6

8 Berlin V and Haseltine WA: Reduction of adriamycin to a semiquinone-free radical by NADPH cytochrome P-450 reductase produces DNA cleavage in a reaction mediated by molecular oxygen. J Biol Chem 256(10): 4747-4756, 1981. PMID: 6262301.

9 Rumyantseva GV, Weiner LM, Frolova EI and Fedorova OS: Hydroxyl radical generation and DNA strand scission mediated by natural anticancer and synthetic quinones. FEBS Lett 242(2): 397-400, 1989. PMID: 2536625. DOI: 10.1016/00145793(89)80509-5 
10 Celik $\mathrm{H}$ and Arinç E: Bioreduction of idarubicin and formation of ROS responsible for DNA cleavage by NADPH-cytochrome P450 reductase and its potential role in the antitumor effect. J Pharm Pharm Sci 11(4): 68-82, 2008. PMID: 19183515.

11 Żwierełło W, Maruszewska A, Nowak R, Kostrzewa-Nowak D and Tarasiuk J: DNA damage induced by NADPH cytochrome $\mathrm{P} 450$ reductase-activated idarubicin in sensitive and multidrug resistant MCF7 breast cancer cells. Pharmacol Rep 69(1): 185195, 2017. PMID: 27940401. DOI: 10.1016/j.pharep.2016. 10.002

12 Mizutani H, Oikawa S, Hiraku Y, Murata M, Kojima M and Kawanishi S: Distinct mechanisms of site-specific oxidative DNA damage by doxorubicin in the presence of copper(II) and NADPH-cytochrome P450 reductase. Cancer Sci 94(8): 686691, 2003. PMID: 12901793. DOI: 10.1111/j.1349-7006. 2003.tb01503.x

13 Mizutani H, Tada-Oikawa S, Hiraku Y, Kojima M and Kawanishi S: Mechanism of apoptosis induced by doxorubicin through the generation of hydrogen peroxide. Life Sci 76(13): 1439-1453, 2005. PMID: 15680309. DOI: 10.1016/ j.lfs. 2004.05 .040

14 Mizutani H, Nishimoto A, Hotta S, Ikemura K, Imai M, Miyazawa D, Ohta K, Ikeda Y, Maeda T, Yoshikawa M, Hiraku $\mathrm{Y}$ and Kawanishi S: Oxidative DNA damage induced by pirarubicin, an anthracycline anticancer agent, in the presence of copper(II). Anticancer Res 38(5): 2643-2648, 2018. PMID: 29715084. DOI: 10.21873/anticanres.12506

15 Mizutani H, Hayashi Y, Hashimoto M, Imai M, Ichimaru Y, Kitamura Y, Ikemura K, Miyazawa D, Ohta K, Ikeda Y, Maeda T, Yoshikawa M, Hiraku Y and Kawanishi S: Oxidative DNA damage and apoptosis induced by aclarubicin, an anthracycline: role of hydrogen peroxide and copper. Anticancer Res 39(7): 3443-3451, 2019. PMID: 31262868. DOI: 10.21873/anticanres.13490

16 Ohnishi S, Mizutani H and Kawanishi S: The enhancement of oxidative DNA damage by anti-diabetic metformin, buformin, and phenformin, via nitrogen-centered radicals. Free Radic Res 50(8): 929-937, 2016. PMID: 27328723. DOI: $10.1080 / 10715$ 762.2016 .1204651

17 Mizutani H, Hiraku Y, Tada-Oikawa S, Murata M, Ikemura K, Iwamoto T, Kagawa Y, Okuda M and Kawanishi S: Romidepsin (FK228), a potent histone deacetylase inhibitor, induces apoptosis through the generation of hydrogen peroxide. Cancer Sci 101(10): 2214-2219, 2010. PMID: 20624163. DOI: 10.1111/j.1349-7006.2010.01645.x

18 Toyokuni S, Tanaka T, Hattori Y, Nishiyama Y, Yoshida A, Uchida K, Hiai H, Ochi $\mathrm{H}$ and Osawa $\mathrm{T}$ : Quantitative immunohistochemical determination of 8-hydroxy-2'deoxyguanosine by a monoclonal antibody N45.1: its application to ferric nitrilotriacetate-induced renal carcinogenesis model. Lab Invest 76(3): 365-374, 1997. PMID: 9121119.

19 Platel D, Pouna P, Bonoron-Adèle S and Robert J: Comparative cardiotoxicity of idarubicin and doxorubicin using the isolated perfused rat heart model. Anticancer Drugs 10(7): 671-676, 1999. PMID: 10507317. DOI: 10.1097/00001813-19990800000007
20 Hiraku Y, Goto H, Kohno M, Kawanishi S and Murata M: Metal-mediated oxidative DNA damage induced by methylene blue. Biochim Biophys Acta 1840(9): 2776-2782, 2014. PMID: 24792575. DOI: 10.1016/j.bbagen.2014.04.020

21 Pryor WA and Tang RH: Ethylene formation from methional. Biochem Biophys Res Commun 81(2): 498-503, 1978. PMID: 666768. DOI: 10.1016/0006-291x(78)91562-0

22 Ozluer $\mathrm{C}$ and Kara HE: In vitro DNA binding studies of anticancer drug idarubicin using spectroscopic techniques. J Photochem Photobiol B 138: 36-42, 2014. PMID: 24911270. DOI: $10.1016 /$ j.jphotobiol.2014.05.015

23 Sakano K, Oikawa S, Hasegawa K and Kawanishi S: Hydroxyurea induces site-specific DNA damage via formation of hydrogen peroxide and nitric oxide. Jpn J Cancer Res 92(11): 1166-1174, 2001. PMID: 11714440. DOI: 10.1111/j.13497006.2001.tb02136.x

24 Ogawa K, Hiraku Y, Oikawa S, Murata M, Sugimura Y, Kawamura J and Kawanishi S: Molecular mechanisms of DNA damage induced by procarbazine in the presence of $\mathrm{Cu}(\mathrm{II})$. Mutat Res 539(1-2): 145-155, 2003. PMID: 12948823. DOI: 10.1016/s1383-5718(03)00157-8

25 Murata M, Suzuki T, Midorikawa K, Oikawa S and Kawanishi $\mathrm{S}$ : Oxidative DNA damage induced by a hydroperoxide derivative of cyclophosphamide. Free Radic Biol Med 37(6): 793-802, 2004. PMID: 15304255. DOI: 10.1016/j.freerad biomed.2004.05.009

26 Iwamoto T, Hiraku Y, Okuda M and Kawanishi S: Mechanism of UVA-dependent DNA damage induced by an antitumor drug dacarbazine in relation to its photogenotoxicity. Pharm Res 25(3): 598-604, 2008. PMID: 17710513. DOI: 10.1007/s11095007-9413-2

27 Rehman SU, Zubair H, Sarwar T, Husain MA, Ishqi HM, Nehar $\mathrm{S}$ and Tabish M: Redox cycling of $\mathrm{Cu}(\mathrm{II})$ by 6-mercaptopurine leads to ROS generation and DNA breakage: Possible mechanism of anticancer activity. Tumour Biol 36(2): 1237-1244, 2015. PMID: 25344215. DOI: 10.1007/s13277-014-2743-x

28 Nagaj J, Kołkowska P, Bykowska A, Komarnicka UK, Kyzioł A and Jeżowska-Bojczuk M: Interaction of methotrexate, an anticancer agent, with copper(II) ions: coordination pattern, DNA-cleaving properties and cytotoxic studies. Med Chem Res 24: 115-123, 2015. PMID: 25589824.

29 Sinha BK, Antholine WM, Kalyanaraman B and Eliot HM: Copper ion-dependent oxy-radical mediated DNA damage from dihydroxy derivative of etoposide. Biochim Biophys Acta 1096(1): 81-83, 1990. PMID: 2176549.

30 Denoyer D, Masaldan S, La Fontaine S and Cater MA: Targeting copper in cancer therapy: 'Copper That Cancer'. Metallomics 7(11): 1459-1476, 2015. PMID: 26313539. DOI: 10.1039/ $\mathrm{c} 5 \mathrm{mt} 00149 \mathrm{~h}$

Received August 8, 2020

Revised September 1, 2020

Accepted September 3, 2020 